\title{
SILÓSZÁRÍTÓK SZEMCSEMOZGÁS VISZONYAINAK ELEMZÉSE
}

\section{ANALYSIS OF PARTICLE MOVEMENT CONDITIONS OF SILODRYER}

\author{
Varga Attila \\ NAIK Mezögazdasági Gépesitési Intézet, Magyarország, Gödöllö, Szent-Györgyi Al- \\ bert út 4; Telefon: +36 (28) 511-601,varga.attila@gmgi.hu
}

\begin{abstract}
Mixing is one of the most important and most essential proccess in agriculture. For the drying of the granular materials, the particle velocity distribution around the mixing screws and the mixing efficienty must be determined. The causeless increase of screw angular velocity results higher power consumption and quality degradation. Experimental apparatus have to be planned for the examination of particle motion around open mixing screws. In our article we would like to demonstrate, that most of the costly experiments can be omitted, if we have a properly calibrated discrete element model of the mixing process.
\end{abstract}

Keywords: silodryer, discrete element method, experimental apparatus.

\section{Összefoglalás}

A keverés az egyik legfontosabb és legalapvetőbb művelet a mezőgazdaságban. Szemes termények szárításánál a keverőcsigák körül kialakult szemcsemozgások, valamint a keverési hatékonyság meghatározásának elmélete még nem teljesen kiforrott. A keverő berendezések nem megfelelő fordulatszámon való üzemeltetése nagyobb energiafelhasználással és a termény minőségének károsodásával járhat. A kialakult szemcsemozgások meghatározásához kísérleti berendezést kellett létrehozni. Munkánk során, a mérési eredményeket összevetettük a diszkrét elemes szimulációval kapott eredményekkel.

Kulcsszavak: silószáritó,diszkrét elemek módszere, kísérleti berendezés.

\section{A kísérleti vizsgálatok}

\subsection{Tárolórendszerü szárítóberende- zések}

A szemestermények szárító berendezései közé tartoznak a vastagrétegü szárítók. A vastagrétegü szárítók esetén a szárítani kívánt anyagréteg több méter vastagságú. Ezek a szárítók a termény tárolására is kiválóan alkalmasak. Az ilyen berendezéseket silószárítóknak nevezik. Ezen típusú szárítók esetében is a legnagyobb problémát az jelenti, hogy a folyamat végeztével az anyag nedvességtartalmának eloszlása nem lesz homogén. Az inhomogenitás csökkentésére számos módszer létezik. A korszerü berendezéseknél, egy a siló tetejére szerelt terménykeverő rendszer segítségével csökkentik az inhomogenitást.[1] Az üzemeltetés során fellépő terhelések az önsúlyból, a mozgások okozta erőhatásokból és a keve- 
rőcsigák által megmozgatott anyag tömegétől és mechanikai tulajdonságaitól függenek.

\subsection{A kísérleti berendezés létrehozá- sa}

A keverőcsigák által létrehozott szemcsemozgás viszonyok meghatározására kísérleti berendezést hoztunk létre (1.ábra). A berendezés tároló része egy $450 \mathrm{~mm}$ átmérőjü és $3 \mathrm{~mm}$ falvastagságú átlátszó plexi henger. A henger közepén helyezkedik el a keverő csiga, melyet egy hajtómotor forgat ékszíj hajtás segítségével.

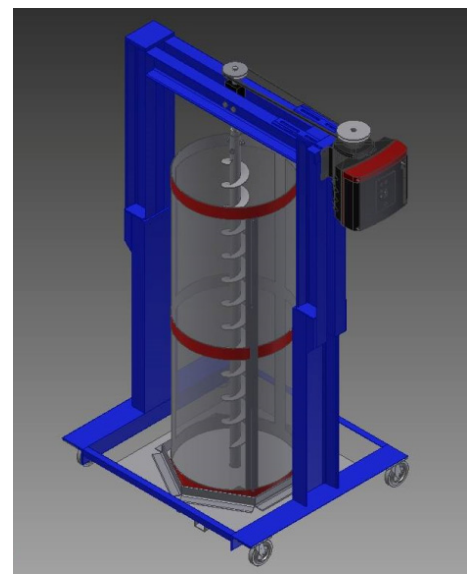

1. ábra. Az kisérleti berendezés 3D-s modellje

A vizsgálatokat búza halmazzal végeztük. A szemcsék mozgásának meghatározásához egy színezett búza réteget helyeztünk el adott magasságban, a hengerben. Adott fordulatszám megtétele után kis átmérőjü, alul zárható plexi csövek segítségével, mintákat vettünk a halmazból (2.ábra). A mintavevő csőben a színezett réteg elhelyezkedéséből adódóan meghatározható, hogy mekkora a színezett szemek függőleges elmozdulása. A következő lépésben megalkottuk a berendezés és a szemcsehalmaz diszkrét elemes modelljét és az adott fordulatszám megtétele után vizsgáltuk az elmozdulásmezőt. A mérési eredmények lehetővé tették a szimulációk validálását.

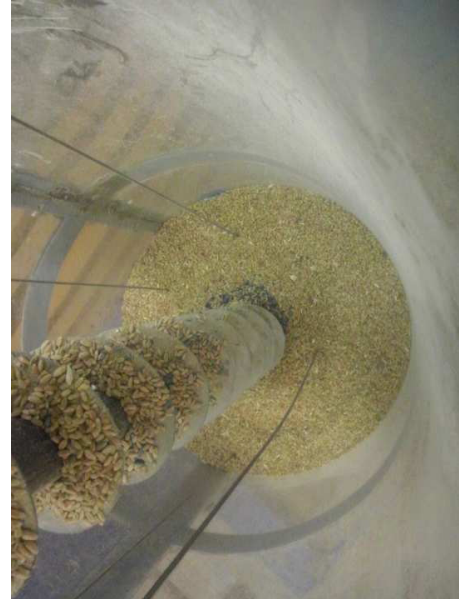

2. ábra. A berendezés és a mintavevő pontok

Azt tapasztaltuk, hogy a mérési eredmények és a diszkrét elemes szimulációk jó egyezést mutattak. A diszkrét elemes módszer tehát alkalmas a keverôcsiga körül kialakult szemcse-elmozdulásmező vizsgálatára.

\section{A szemcse mozgásviszonyok elemzése}

\subsection{A diszkrét elemek módszere}

A diszkrét elemes módszer (DEM) egy új numerikus eljárás a szemcsés halmazok mechanikai viselkedésének modellezésére. A DEM szimuláció lényege, hogy az összes részecske mozgásegyenletét egyenként oldjuk meg. A diszkrét elemes megközelítés nagyon hatékony, mert annak eredményei sokkal komplexebb geometriára kiterjeszthetők, mint az analitikus közelítés eredményei. A diszkrét elemes közelítés a szemcsés anyagot az egyes szemcsék mechanikai viselkedésének nyomon követésével modellezi. A közelítés során a halmazt idealizált tulajdonságokkal rendelkező szemcsék öszszességének tekintik. A szemcsék mechanikai kölcsönhatását erők és nyomatékok segítségével modellezik. [2] 


\subsection{A keverőcsiga diszkrét elemes modellje}

A keverőcsigák körül kialakult szemcse mozgások modellezésére diszkrét elemes módszert használtunk. A szimulációban alkalmazott búza és keverőcsiga mikromechanikai paramétereit a következö táblázat mutatja [3].

1. táblázat. A búza és az acél mechanikai jellemzöi

\begin{tabular}{|c|c|c|c|c|}
\hline - & \multicolumn{2}{|c|}{ Búza } & \multicolumn{2}{|c|}{ Acél } \\
\hline$v[-]$ & \multicolumn{2}{|c|}{0.4} & \multicolumn{2}{|c|}{0.3} \\
\hline $\mathrm{G}[\mathrm{MPa}]$ & \multicolumn{2}{|c|}{$3.58 \cdot 10^{8}$} & \multicolumn{2}{|c|}{$8 \cdot 10^{10}$} \\
\hline$\rho\left[\mathrm{kgm}^{-3}\right]$ & \multicolumn{2}{|c|}{1460} & \multicolumn{2}{|c|}{7500} \\
\hline $\mathrm{C}_{\mathrm{r}}[-]$ & \multicolumn{2}{|c|}{0.5} & \multicolumn{2}{|c|}{0.6} \\
\hline$\mu_{0}[-]$ & 0.3 & 0.6 & 0.25 & 0.45 \\
\hline$\mu_{\mathrm{r}}[\mathrm{m}]$ & \multicolumn{2}{|c|}{0.01} & \multicolumn{2}{|c|}{0.01} \\
\hline
\end{tabular}

A táblázatban szereplő jelölések:

- $\quad v$ : Poisson tényező

- G: csúsztató rugalmassági modulus

- $\rho$ : sürüség

- $\mathrm{C}_{\mathrm{r}}$ : ütközési tényezö

- $\mu_{0}$ : a szemek közötti súrlódási tényező

- $\quad \mu_{\mathrm{r}}$ : gördülési ellenállás tényezője

A 3. ábrán egy búzaszem diszkrét elemes modellje látható.

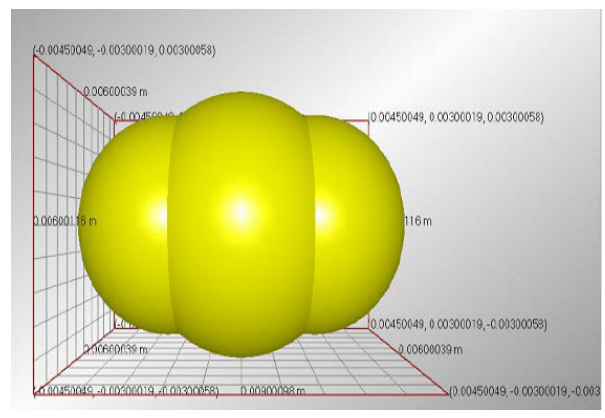

3. ábra. Egy búzaszem diszkrét elemes modellje
A szemet 3 egymásba metsző gömb segítségével modelleztük. A középső gömb átmérője $3 \mathrm{~mm}$, a két szélső gömbbé 2 $\mathrm{mm} .[3]$

A szimuláció során csak a búzaszemcsék és a keverőcsiga kölcsönhatásával foglalkoztunk, a szemcsék és a plexihenger kölcsönhatásától eltekintettünk. Mivel az általunk kiemelt hengeres tartomány környezetében a valóságban szintén szemestermény van, a modellezés során a henger anyagtulajdonságai megegyeznek a búzáéval. A szimulációban használt keverőcsiga és henger méretei megegyeznek a kísérleti berendezés méreteivel. Különböző szögsebességek mellett vizsgáltuk az elmozdulásmezőt és a sebességmezőt. Egy tipikus sebességmezőt mutat a 4. ábra.
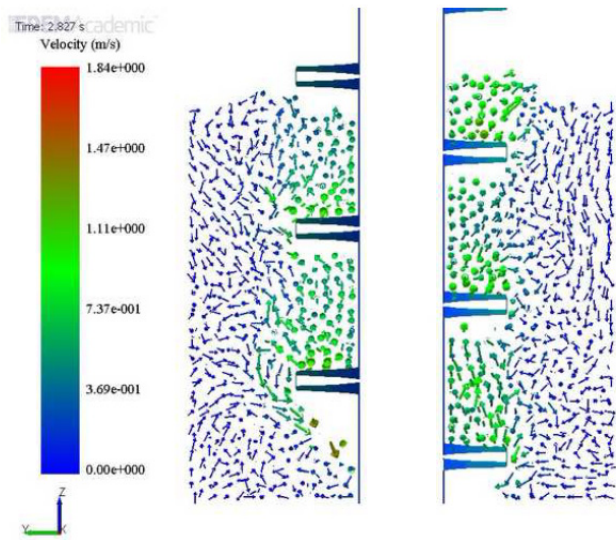

4. ábra. A sebességeolszlás a keveröcsiga körül

Az ábrán az látható, hogy a keverőcsiga közvetlen környezetében a csiga felfelé szállítja a szemcséket és az elszállított szemcsék helyére újak áramolnak be. A csigától egy bizonyos távolságra viszont a szemcsék lefelé irányú mozgása figyelhető meg. Ebböl a három mozgásból tevődik össze a keverés folyamata. A szimulációk során meghatároztuk azt a tartományt, ahol a keverés még megfigyelhető. A keverés hatékonyságának meghatározásához bevezettük az effektív sugár fogalmát. Ez az a 
csiga hossztengelyétől mért távolság, amelynél a szemcsék csiga-tengely irányú sebessége a sugár mentén fellépő maximális csiga-tengely irányú sebesség értékének 10\%-ával egyenlő. Az effektív sugár bevezetésével összehasonlíthatóvá válnak a különböző csigalevél átmérővel, különböző fordulatszám mellett kapott eredmények. Ezen kívül egy másik módszert is alkalmaztunk, hogy jellemezük a keverés hatékonyságát. A módszer lényege az volt, hogy a szimuláció során a hengerben elhelyeztünk 5000 db „nedves” szemcsét, majd az így kapott halmaz tetéjére még további 15000 db „száraz” szemcse került. A keverés elindítása után meghatároztuk, hogy mennyi „nedves” szemcse keveredett az eredeti 15000 db „, száraz” szemcse közé.

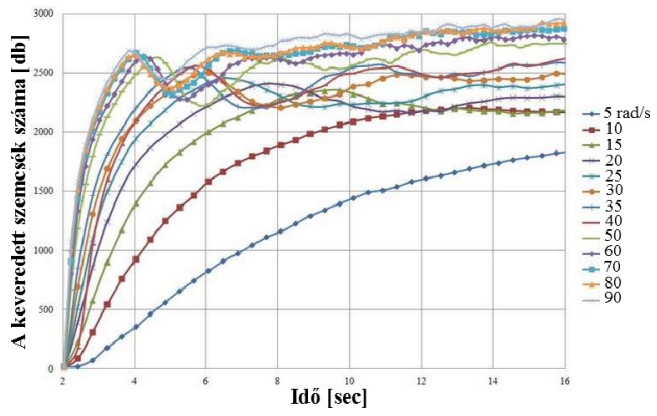

5. ábra. Az elkeveredett szemcsék számának alakulása különbözö fordulatszámok mellett

Az 5. ábráról leolvasható, hogy a fordulatszám növelésével egyre több „nedves” szemcse keveredik el, ami abból adódik, hogy a gyorsabban forgó csiga több anyagot kever át. Azonban egy adott fordulatszám elérése után az elkeveredett szemcsék száma, azaz a keverési hatékonyság nem nő tovább.

\section{Következtetések}

- A tervezett keverő berendezéssel validálhatók a diszkrét elemes szimulációk eredményei

- A diszkrét elemes módszer alkalmas a vastagrétegü szárítókban használt keverőcsigák által létrehozott szemcse mozgás viszonyok modellezésére;

- Létezik egy optimális fordulatszám, ami, mely felett már nem javul a keverés hatékonysága.

\section{Köszönet}

Köszönetet mondok Takács Sándor kollégának a sikeres közremüködésért a kísérleti berendezés létrehozásában és megvalósításában.

\section{Szakirodalmi hivatkozások}

[1] Arun S. M, Beke J.: Gyakorlati száritás, Szaktudás Kiadó Ház Budapest, 2002.

[2] P.A. Cundall, O.D.L. Strack: A discrete numerical model for granular assemblies, Geotechnique 29 (1) (1979) 47-65.

[3] Istvan Keppler, Laszlo Kocsis, Istvan Oldal, Istvan Farkas, Attila Csatar: Grain velocity distribution in a mixed flow dryer, Advanced Powder Technology 23 (2012), 824-832. 